\title{
1 Glycyrrhizin inhibits LPS-induced inflammatory responses 2 in goat ruminal epithelial cells in vitro
}

3 Xuanxuan $\mathrm{Pu}^{\mathrm{a}, 1}$, Pattygouri Mullahred ${ }^{\mathrm{a}, 1}$, Junfeng Liu ${ }^{\mathrm{ab}}$, Xuefeng Guo ${ }^{\mathrm{ab} *}$, Jian Gao ${ }^{\mathrm{c}}$, Xiuping

$4 \quad$ Zhang ${ }^{\mathrm{ab}}$, Chenyu Jiang ${ }^{\mathrm{a}}$, Sujiang Zhangab

$5 \quad{ }^{a}$ College of Animal Science, Tarim University, Alar 843300, Xinjiang, PR China

$6 \quad{ }^{\mathrm{b}}$ Key Laboratory of Tarim Animal Husbandry Science and Technology of Xinjiang Production

7 and Construction Group, Alar 843300, Xinjiang, PR China

$8{ }^{c}$ College of Animal Science and Technology, Yangzhou University, Yangzhou 225009, Jiangsu,

$9 \quad$ PR China

10

11

$12{ }^{1}$ Xuanxuan Pu and Pattygouri Mullahred equally contributed to this work.

$13{ }^{*}$ Corresponding authors. Tel.: 15299571979.

14 Email address: gxfdky@126.com.

15 


\section{Abstract}

A long-term of high concentration feeding in ruminants can bring huge economic profits,

SARA is a kind of disease which attenuate the health, feed intake and production of ruminants, and when ruminants suffer SARA, the concentration of lipopolysaccharide (LPS) increase largely.

Glycyrrhizin is reported to have anti-inflammation effects, and the study was conducted to investigate effects of glycyrrhizin on LPS-induced goat ruminal epithelial cells (GRECs) to provide evidence for using glycyrrhizin as a treatment for SARA. Effects of LPS, and glycyrrhizin on cell viability of GRECs were investigated, respectively. Then GRECs were stimulated with LPS (50 mg/L) for $2 \mathrm{~h}$, and glycyrrhizin were added at the concentration of 0, 50, 75, 100 and 125 $\mathrm{mg} / \mathrm{L}$ for $24 \mathrm{~h}$ to investigate the expression of inflammatory cytokines (by Elisa kits), the mRNA

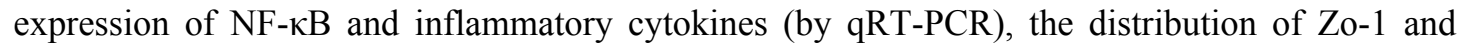
Occludin (by immunofluorescence staining), the expression of Occludin (by Western blot analysis), and the morphology of GRECs. The results showed that: (1) Glycyrrhizin at the concentration of $50,75,100$, and $125 \mathrm{mg} / \mathrm{L}$ had no cytotoxic effects on GRECs, and LPS at the concentration of $50 \mathrm{mg} / \mathrm{L}$ significantly decreased the cell viability of GRECs. (2) Glycyrrhizin 
by a dose-dependent manner, and significantly attenuated the relative mRNA expression of NF-kB. (3) Immunofluorescence staining and Western blot analysis showed that the quantity of Zo-1 and Occludin, and the expression of Occludin all increased with the treatment of glycyrrhizin. (4) Glycyrrhizin attenuated LPS-induced autophagy and protected the structural integrity of GRECs. In conclusion, glycyrrhizin significantly inhibited the inflammatory response in LPS-stimulated GRECs, and it may be used as a potential agent for the treatment of SARA.

Key words: glycyrrhizin; GRECs; LPS; inflammation; SARA

\section{Introduction}

SARA has become one of the most harmful and common diseases in ruminants breeding as more concentration were fed for the growing demand of animal productions (Hong et al., 2010). Researches showed that the incidence of ruminants' SARA in Italy, Ireland, Netherlands and the United States were 33\%, 13.8\%, 11\% and 19\%-20.1\%, respectively (Morgante et al., 2007; Kleen et al., 2009; Luke et al., 2008; Garrett et al., 1999). Yamamoto et al. (1993) reported that the rumen of fattening cattle was in a low acid environment for a long time when it suffered SARA, and finally led to the shedding of ruminal mucosa. Ruminal epithelium play a crucial role in defensing against bacteria (Wu et al., 2013), however, SARA could damage the cell viability and barrier function of ruminal epithelial cells. Even worse, systemic inflammatory response would be aroused when toxin and inflammatory substances crossed the mucosal barrier and reached to blood circulation (Penner et al., 2010). LPS is a main toxin product of Gram negative bacteria, and the concentration of free LPS in the rumen increases sharply when ruminants are under SARA. LPS fastened the release of inflammatory factors such as TNF- $\alpha$, IL-1 $\beta$ and IL-6 (Yan et 
al., 2014). The mechanism of that is as follows: LPS leads to the activation of TLR4 signal pathway causing the release of inflammatory cytokines. Meanwhile, the NF- $\mathrm{kB}$ pathway, which has key regulatory functions in inflammation and innate and adaptive immunity (Rietschel et al., 1987), was also activated by LPS, and it further hastened the release of inflammatory cytokines. Histopathological change of GRECs was observed when LPS entered into rumen tissues.

Autophagy, as a survival mechanism of cells in adverse environments, can remove damaged organelle and protein to protect cells (Zhu et al., 2011). Autophagy has been demonstrated to be widely involved in various disease processes, including cardiovascular disease, cancer, and neurodegenerative diseases (Lisa et al., 2012; Poon et al., 2012; Poon et al., 2012). Autophagy was also observed in GRECs when ruminants were under SARA as well. However, excessive autophagy could lead to large death of cells. Thus, we need to find agent that could prevent and treat inflammation when ruminants were under SARA.

Glycyrrhizin, isolated from licorice, has been reported to have anti-oxidative (Haraguchi et al., 1998; Vaya et al., 1997) and anti-inflammatory effects (Yamashita et al., 2017; Gonzalez-Reyes et al., 2016). Glycyrrhizin could be used to prevent some disease and to improve meat quality (Okamoto et al., 2001; Shibayama et al., 1989). Thus, we made a hypothesis that glycyrrhizin could reduce the inflammatory response in GRECs and provide treatment for SARA. But there was less research investigating on anti-inflammatory effects of glycyrrhizin on LPS-induced GRECs. Therefore, in this study, GRECs were stimulated with LPS, and the effects of glycyrrhizin in LPS-stimulated GRECs were investigated in vitro to provide evidence for using glycyrrhizin as a method to treat ruminants under SARA. 
82

\section{Materials and Methods}

\section{Reagents}

Glycyrrhizin (purity >99\%) was purchased from Yuanye Biotechnology Co., Ltd. (Shanghai, China). LPS (Escherichia coli 055:B5) was purchased from Sigma Chemical (St. Louis, MO, USA). Fetal bovine serum were purchased from Gibco (Grand Island, New York, USA). DMEM/F12 was purchased from Hyclone (Beijing, China). Anti-cytokeratin-18 IgG and FITC-goat anti mouse IgG were purchased from Santa cruz biotechnology Co., Ltd. (America). Anti-rabbit IgG H\&L was purchased from Abcam (America). DAPI were purchased from Tongren institute of chemistry (Japan). Elisa kits for TNF- $\alpha$, IL-1 $\beta$, IL-6, IL-8 and IL-12 were gotten from Biolegend (Camino Santa Fe, CA, USA). BCA protein quantitative kit and SYBR Green PCR kit were purchased from Smer Fell Science and Technology Co., Ltd. (Shanghai, China). RIPA, Acrylamide(29:1), Tris- $\mathrm{HCl} \mathrm{pH}=8.8$ electrophoretic buffer, Tris- $\mathrm{HCl} \mathrm{pH}=6.8$ electrophoretic buffer, SDS, TEMED, PBS phosphate buffer and DEPC were purchased from JRDUN Biotechnology Co., Ltd. (Shanghai, China). $\beta$-actin was purchased from Tianjin Sungene Biotech Co. (Tianjin, China). Alexa Fluor 488 Labeled goat anti-rabbit IgG (H+L), DAPI, Goat anti-rabbit-HRP secondary sera, Donkey anti-goat-HRP secondary sera and Goat anti-mouse-HRP secondary sera were purchased from Biyuntian biotechnology co., Ltd. (Shanghai, China). Occludin (rabbit) and ZO-1 (rabbit) were purchased from Aobasen biotechnology co., Ltd (Beijing, China). DMEM/F12 was purchased from Hyclone (Los Angeles, USA), MiniBEST Universal RNA Extraction Kit was purchased from TaKaRA, iScript ${ }^{\mathrm{TM}}$ gDNA Clear Synthesis Kit was purchased from Bio-Rad. 
103

\section{Animals and treatment}

\section{Cell culture, treatment and identification}

from goats. Primary rumianl epithelial cells were obtained as described in previous study (Zhao et al., 2019). Primary cells were purified, and were identified by the method of cytokeratin-18 immunocytochemistry.

\section{Cell viability assay}

The cell viability of LPS, and glycyrrhizin in GRECs were measured by [3-(4,5-dimethylthiazol-2-yl)-2,5-diphenyl-tetra-zoliumbromide] (MTT) assay, respectively. The GRECs were treated with $100 \mu \mathrm{L}$ of LPS $(50 \mathrm{mg} / \mathrm{L})$, and glycyrrhizin $(0,50,75,100$ and 125 $\mathrm{mg} / \mathrm{L}$ ) for $24 \mathrm{~h}$, respectively, and then $10 \mu \mathrm{L}$ of $5 \mathrm{mg} / \mathrm{L}$ MTT was added for $4 \mathrm{~h}$. Finally, the supernatants were removed and dissolved with $150 \mathrm{ml}$ of DMSO in each well. Absorbance was determined at $570 \mathrm{~nm}$.

\section{Inflammatory cytokines assay}




\section{Primers design and synthesis}




$\begin{array}{lll}\text { IL-6 } & \text { F: TACCTGGACTTCCTCCAGAAC } & 245 \\ \text { (NM_001285640.1) } & \text { R: CGAATAGCTCTCAGGCTGAAC } \\ \text { IL-8 } & \text { F: TCTTGGCCGCTTTCCTGCTC } & 162 \\ \text { R: TTTCGCAGTGTGGCCCACTC } & \\ \text { IL-12 } & \text { F: GACCAAACCTCAGCCAAAG } & 104 \\ \text { (NM-001285700.1) } & \text { R: GACACAGATGCCCATTCAC } \\ \text { FAPDH } & \\ \text { (XM_005680968.3) } & \text { R: GCGGATGTCGACGTCACA } \\ \end{array}$

RNA extraction and reverse transcription Co., Ltd. 
bioRxiv preprint doi: https://doi org/10.1101/2020.05.27.118570; this version posted May 28,2020 . The copyright holder for this preprint (which was not certified by peer review) is the author/funder, who has granted bioRxiv a license to display the preprint in perpetuity. It is made available under aCC-BY 4.0 International license.

144 primer $\mathrm{R}, 9.5 \mu \mathrm{L}$ ddH ${ }_{2} \mathrm{O}, 2 \mu \mathrm{L}$ cDNA template. The response procedures were: $95^{\circ} \mathrm{C}, 10 \mathrm{~min}(95$

$\left.{ }^{\circ} \mathrm{C}, 15 \mathrm{~s} ; 60^{\circ} \mathrm{C}, 45 \mathrm{~s}\right) \times 40 ; 95^{\circ} \mathrm{C}, 15 \mathrm{~s} ; 60^{\circ} \mathrm{C}, 1 \mathrm{~min} ; 95^{\circ} \mathrm{C}, 15 \mathrm{~s} ; 60{ }^{\circ} \mathrm{C}, 15 \mathrm{~s}$.

The distribution and quantity of Occludin and Zo-1

The distribution and quantity of Occludin and Zo-1 was measured by immunofluorescence

staining. GRECs were treated as mentioned above, the slides of GRECs were washed with $0.02 \mathrm{M}$

PBS in the culture plate, fixed by $4 \%$ paraformaldehyde for $30 \mathrm{~min}$, permeabilized by $0.1 \%$ Triton

$\mathrm{X}-100$, blocked by $1 \%$ bovine serum albumin (BSA) for $1 \mathrm{~h}$, and each step followed three times

washing by $0.02 \mathrm{M}$ PBS. Cell slides was incubated overnight at $4^{\circ} \mathrm{C}$ in a wet box with a specific

primary antibody (1:50), and cell slides were washed by $0.02 \mathrm{M}$ PBS for three times. Then cell

labeled with fluorescein isothiocyanate (1:500), and then washed by $0.02 \mathrm{M}$ PBS for three times, in a $-20^{\circ} \mathrm{C}$, and photographed by a fluorescence microscope.

\section{Western blot analysis}


165

primary antibody at $4{ }^{\circ} \mathrm{C}$ for $12 \mathrm{~h}$ and then incubated with a secondary antibody at $37{ }^{\circ} \mathrm{C}$ for $1 \mathrm{~h}$.

Finally, the blots were developed with the ECL Plus Western Blotting Detection System (GE Healthcare, Chalfont St Giles, UK).

\section{Morphology change of LPS-induced GRECs}

To further identify anti-inflammatory effects of glycyrrhizin, the morphology of GRECs was investigated as well. GRECs treated as mentioned above were washed by PBS, resuspended and sealed by $2.5 \%$ glutaraldehyde for $2 \mathrm{~h}$ and washed by PBS for three times. Then tissues were sealed by osmic acid for $2.5 \mathrm{~h}$ and washed by PBS for three times. Tissues were dehydrated with different concentration ethanol of $30 \%, 50 \%, 70 \%, 90 \%, 95 \%$ and $100 \%$, each dehydration lasted for 10-15 min for three times. Then tissues were replaced with propylene epoxide for two times, each time last for $10 \mathrm{~min}$. Tissues were permeated by propylene oxide and epon resinand at a 2:1 ratio and by propylene oxide and epon resinand at a 1:2 ratio for $2 \mathrm{~h}$, respectively, then tissues were permeated by whole epon resinand for the night. Tissues were polymerizated at $37^{\circ} \mathrm{C}$ for 12 $\mathrm{h}, 45^{\circ} \mathrm{C}$ for $24 \mathrm{~h}$ and $60^{\circ} \mathrm{C}$ for $48 \mathrm{~h}$, and finally, the tissues were made into cell slice and observed by electron microscopic.

\section{Statistical analysis}

All data was presented as the means \pm S.E.M by SPSS 16.0. Difference were performed by one-way ANOVA combined with Turkey's multiple comparison tests. Differences were considered to be significant at $P<0.05(*)$, extremely significant at $P<0.01(* *)$.

\section{Results}




\section{The cytokeratin-18 expression of cells}

The purified epithelial cells were identified by the detection of cytokeratin-18, and the result was shown in Fig. 1. Green fluorescence was showed in our result, and the positive staining for cytokeratin-18 indicated that the purified ruminal epithelial cells were GRECs.

\section{Effects of LPS and glycyrrhizin in cell viability of GRECs}

As shown in Fig. 2, the cell viability in groups added with glycyrrhizin at the concentration of 50, 75, 100 and $125 \mathrm{mg} / \mathrm{L}$ had no significant difference versus control group. The cell viability of GRECs stimulated by LPS was significantly decreased.

\section{Effects of glycyrrhizin on inflammatory cytokines in LPS-induced GRECs}

As shown in Fig. 3, the production of TNF- $\alpha$, IL-1 $\beta$, IL-6, IL-8 and IL-12 in LPS group were extremely significant higher than those with the treatment of glycyrrhizin $(P<0.01)$. Glycyrrhizin at the concentration of $50,75,100$ and $125 \mathrm{mg} / \mathrm{L}$ inhibited the production of cytokines by a dose-dependent manner.

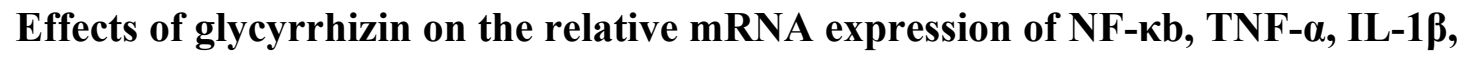

\section{IL-6, IL-8 and IL-12 in LPS-induced GRECs}

As shown in Fig. 4, glycyrrhizin at the concentration of 50, 75, 100 and $125 \mathrm{mg} / \mathrm{L}$ inhibited the mRNA expression of TNF- $\alpha$, IL-1 $\beta$, IL-6, IL-8 and IL-12 in LPS group by a dose-dependent manner $(P<0.01)$. Glycyrrhizin added at the concentration of 75, 100 and 125 $\mathrm{mg} / \mathrm{L}$ decreased the mRNA expression of NF-kb significantly. 


\section{GRECs} glycyrrhizin.

\section{Effect of glycyrrhizin on the morphology of LPS-induced GRECs}

\section{Discussion}




\section{Cell viability of glycyrrhizin in GRECs}

When ruminants were under SARA, the rumen mucosal barrier was impaired, and the content of LPS increased sharply (Rodríguez-Lecompte et al., 2014; Khafipour et al., 2009). The mRNA expression of inflammatory cytokines was increased significantly in LPS-induced ruminal epithelium of dairy cattle (Zhang et al., 2016). The tight connection between GRECs was destroyed (Liu et al., 2013), and the inflammatory cytokines would enter into the rumen leading to rumen diseases such as rumen acidosis and the death of the ruminants. Glycyrrhizin which has anti-inflammatory effects in many disease may be used as a potential anti-inflammatory agent for the treatment of SARA. Wang et al (2017) showed that glycyrrhizin at the concentration of 50, 100 , and $200 \mu \mathrm{g} / \mathrm{ml}$ had no cytotoxic effects on mouse endometrial epithelial cells. In our assay, glycyrrhizin (0-125 mg/L) had no cytotoxic effects on GRECs as well.

\section{Effects of glycyrrhizin in LPS-induced GRECs}

It has been reported that glycyrrhiza glabrathe had anti-inflammatory and antiviral effects (Uto et al., 2012). Glycyrrhizin has been reported to inhibit LPS-induced inflammatory cytokines in many cells (Wang et al., 2017; Li et al 2010). Fei et al., (2014) showed that glycyrrhizin decreased the content of TNF- $\alpha$ and IL- 6 significantly in caerulein-induced acute pancreatitis of mice. Kong et al., (2019) showed that glycyrrhizin decreased the content of IL-4 and IL-6 a lot in LPS-induced acute lung injury of mice. $\mathrm{Fu}$ et al., (2014) reported glycyrrhizin inhibited the expression of factor- $\alpha$ and IL-6 in vitro. Similarly, in our study, glycyrrhizin dose-dependently inhibited the production of TNF- $\alpha$, IL-1 $\beta$, IL-6, IL-8 and IL-12. 
inflammatory cytokines increased (Bruewer et al., 2003; Wellnitz et al., 2011), and these

inflammatory cytokines could further activate NF- $\kappa$ B. Stimulating ruminal epithelial cells with

LPS could lead to the activation of NF- $\mathrm{BB}$ signaling pathway (Schaefer et al., 2004), and in our

study, LPS at the concentration of $50 \mathrm{mg} / \mathrm{L}$ had significantly decreased the cell viability of

GRECs. but Strandberg et al., (2005) showed that LPS of $50 \mathrm{mg} / \mathrm{L}$ had no significant effect on could affect the primary mammary epithelial cells of Holstein cows. This difference might be

IL-6, IL-8 and IL-12, which indicate that the inhibition of NF- $\mathrm{BB}$ signaling pathway might lead to the decreased production of inflammatory cytokines, and it needs further investigation. TNF- $\alpha$ is an anti-tumor multi-function factor and large amounts of TNF- $\alpha$ can cause serious inflammatory reactions like tissue necrosis. Research showed that TNF- $\alpha$ could inhibit the expression of expression of Occludin was increased in LPS-induced GRECs, it could further identify the anti-inflammatory effects of glycyrrhizin. 
266 epithelium from mucous layer to serosa layer was stratum corneum, stratum granulosum, stratum

267 spinosum and stratum basale which play an important role in protection. There are tight

268 connection proteins in stratum granulosum and they play an important role in maintaining rumen

269 barrier function (Harhaj et al., 2004; Steele et al., 2011). The tight junction proteins are composed

270 of Claudin, Occludin, Zo-1, ZOs and so on. Sun et al., (2018) reported that when the epithelial

271 cells were under SARA, rumen epithelium and the mRNA expression of tight junction were

272 affected by LPS in vitro. When the ruminal epithelial cells were induced by LPS, the tight junction

273 proteins were destroyed, and the cell gap became larger. In our study, the distribution of Occludin

274 and Zo-1 became uniform and their quantity increased with the treatment of glycyrrhizin. What's

275 more, glycyrrhizin dose-dependently increased the expression of Occludin. The results further

276 identified anti-inflammatory effects of glycyrrhizin in LPS-induced GRECs.

In our study, there was autophagy occurred in LPS-induced GRECs. Autophagy can be

LPS could induce macrophages to produce autophagy. Abnormal activation of autophagy is closely associated with the development of acute pancreatitis (Kang et al., ;Zhang et al., 2011). In our study, glycyrrhizin attenuated the LPS-induced autophagy and dose-dependently decreased the autophagy with high electron density. Therefore, glycyrrhizin inhibited the abnormal activation of autophagy in LPS-induced GRECs.

Taken together, glycyrrhizin dose-dependently inhibited LPS-induced inflammatory response in our study. Therefore, higher concentration of glycyrrhizin should be investigated for 


\title{
Conclusion
}

\author{
Glycyrrhizin (0-125 mg/L) had no cytotoxic effects on GRECs, and LPS significantly \\ decreased the cell viability of GRECs. Glycyrrhizin inhibited the inflammation response in LPS \\ stimulated GRECs by a dose-dependent manner by inhibiting the expression of inflammatory \\ cytokines, suppressing NF-kB signaling pathway, increasing the expression of Occludin and \\ reducing autophagy in LPS-induced GRECs. The comprehensive results showed that glycyrrhizin \\ might be a valuable agent for the treatment of SARA.
}

\section{Conflict of interest statement}

All authors declare that they have no conflict of interest.

\section{Author contributions}

Contributed reagents/materials/analysis/ tools: X.G.; Performed the experiments: X.P; Analyzed the data: X.P; Writing- original draft: X.P.; Writing-review editing: X.P., X.G., C.J., J.L., X.Z., and S.Z..

\section{Acknowledgments}

We acknowledge Dr Long Cheng from the University of Melbourne for useful discussion. This work was supported by the Project of Mr. Yang Sheng's Student Community Research (2016A20006) and Xinjiang Production and Construction Group with the young and middle-aged innovation talents fund (2016BC001).

\section{Reference}


bioRxiv preprint doi: https://doi org/10.1101/2020.05.27.118570; this version posted May 28, 2020. The copyright holder for this preprint

(which was not certified by peer review) is the author/funder, who has granted bioRxiv a license to display the preprint in perpetuity. It is made available under aCC-BY 4.0 International license.

306

307

Bruewer, M., Luegering, A., Kucharzik, T., Parkos, C., Madara, J., Hopkins, A., Nusrat, A., 2003. Proinflammatory Cytokines Disrupt Epithelial Barrier Function by Apoptosis-Independent Mechanisms. Journal of Immunology. 171, 6164-6172.

Chen, Y., Gibson, S.B., 2008. Is mitochondrial generation of reactive oxygen species a trigger for autophagy?. Autophagy. 4, 246-248.

Fei, K., Liang, Z., Ku, H., 2014. The effect and mechanism of Saponins of Radix Glycyrrhiza in mice with acute pancreatitis. Chinese Journal of Modern Medicine. 24, 26-29.

Fu, Y.H., Zhou, E.S., Wei, Z.K., Liang, D.J., Wang, W., Wang, T.C., Guo, M.Y., Zhang. N.S., Yang, Z.T., 2014. Glycyrrhizin inhibits the inflammatory response in mouse mammary epithelial cells and a mouse mastitis model. FEBS Journal. 281, 2543-2557.

Guide for the Care and Use of Laboratory Animals -8th ed[M]. National academis press. 2010.

Garrett, E.F., Pereira, M.N., Nordlund, K.V., Armentano, L.E., Goodger, W.J., Oetzel, G.R., 1999. Diagnostic methods for the detection of subacute ruminal acidosis in dairy cows. Journal of Dairy Science. 82, 1170-1178.

Gonzalez-Reyes, S., Santillan-Cigales, J.J., Jiménez-Osorio, A.S., Pedraza-Chaverri, J., Guevara-Guzman, R., 2016. Glycyrrhizin ameliorates oxidative stress and inflammation in hippocampus and olfactory bulb in lithium/pilocarpine induced status epilepticus in rats. Epilepsy Res. 126, 126-133.

Haraguchi, H., Ishikawa, H., Mizutaki, K., et al., 1998. Antioxidative and superoxide scavenging activities of retrochalcones in Glycyrrhiza inflata Bioorg. Med Chem. 6, 339-347. 
bioRxiv preprint doi: https://doi org/10.1101/2020.05.27.118570; this version posted May 28, 2020. The copyright holder for this preprint

(which was not certified by peer review) is the author/funder, who has granted bioRxiv a license to display the preprint in perpetuity. It is made available under aCC-BY 4.0 International license.

326 Harhaj, S., Antonetti, A., 2004. Regulation of tight junctions and loss of barrier function in pathophysiology. The International Journal of Biochemistry and Cell Biology. 36, 1206.

Hu, H., Lu, D., Liu, D., Shan, D., Li, S., Zhang, C., Shi, Y., 2010. Effects of Different Dietary

Khafipour, E., Krause, D.O., Plaizier, J.C., 2009. Alfalfa pellet-induced subacute ruminal acidosis

Kleen, J.L., Hooijer, G.A., Rehage, J., Noordhuizen, J.P., 2009. Subacute ruminal acidosis in Dutch dairy herds. Vet Rec. 164, 681-683.

Kong, Delei., Wang, Zanfeng., Tian, Jie., Liu, Tingwei., Zhou, Hui., 2019. Glycyrrhizin inactivates toll-like receptor (TLR) signaling pathway to reduce lipopolysaccharide-induced acute lung injury by inhibiting TLR2. Journal of Cellular Physiology. 234, 4597-4607. Mechanism of Total Saponins of Radix Glycyrrhiza in Vitro. Chinese Journal of Experimental Prescriptions. 16(05), 110-113. 
bioRxiv preprint doi: https://doi org/10.1101/2020.05.27.118570; this version posted May 28, 2020. The copyright holder for this preprint

(which was not certified by peer review) is the author/funder, who has granted bioRxiv a license to display the preprint in perpetuity. It is made available under aCC-BY 4.0 International license.

344 Liu, J.H., Xu, T.T., Liu, Y.J., Zhu, W.Y., Mao, S.Y., 2013. A high-grain diet causes massive disruption of ruminal epithelial tight junctions in goats. Am J Physiol Regul Integr Comp Physiol. 305(3), R232-R41.

Lisa, J.M., 2012. Functional Variant in the Autophagy-Related 5 Gene Promotor is Associated with Childhood Asthma. PLoS ONE. 7, e33454.

Luke, O'Grady., Michael, L.D., Finbar, J.M., 2008. Subacute ruminal acidosis (SARA) in grazing Irish dairy cows. Veterinary journal. 44-49.

Morgante, M., Stelletta, C., Berzaghi, P., Gianesella1, M., Andrighetto, I., 2007. Subacute rumen acidosis in lactating cows: an investigation in intensive Italian dairy herds. Journal of Animal Physiology and Animal Nutrition. 91, 226-234.

Oeckinghaus, A., Ghosh, S., 2009. The NF-kappaB family of transcription factors and its regulation. Academic Psychology Bulletin. 1, a000034.

Okamoto, T., Kajino, K., Hino, O., 2001. Hepatoprotective drugs for the treatment of

Penner, G.b., Oba, M., Gäbel, G., Aschenbach, J.R., 2010. A single mild episode of subacute ruminal acidosis does not affect ruminal barrier function in the short term. Journal of Dairy

Poon, A.H., Chouiali, F., Tse, S.M., Litonjua, A.A., Hussain, S.N.A., Baglole, C.J., Eidelman, D.H., Olivenstein, R., Martin, J.G., Weiss, S.T., Hamid, Q., Laprise, C., 2012. Genetic and 

asthma. Autophagy. 8, 694-695.

Rietschel, E.T., Brade, H., Brade, L., Brandenburg, K., Schade, U., Seydel, U., Zhringer, U.,

Rodríguez-Lecompte, J.C., Kroeker, A.D., Ceballos-Márquez, A., Li, S., Plaizier, J.C., Gomez, 
bioRxiv preprint doi: https://doi org/10.1101/2020.05.27.118570; this version posted May 28, 2020. The copyright holder for this preprint

(which was not certified by peer review) is the author/funder, who has granted bioRxiv a license to display the preprint in perpetuity. It is made available under aCC-BY 4.0 International license.

384

385

Steele, M.A., Croom, J., Kahler, M., AlZahal, O., Hook, S.E., Plaizier, K., McBride, B.W., 2011. Bovine rumen epithelium undergoes rapid structural adaptations during grain-induced subacute ruminal acidosis. Am J Physiol Regul Integr Comp Physiol. 300, R1515-R1523.

Strandberg, Y., Gray, C., Vuocolo, T., Donaldson, L., Broadway, M., Tellam, Ross., 2005. Lipopolysaccharide and lipoteichoic acid induce different innate immune responses in bovine mammary epithelial cells. Cytokine. $31,72-86$.

Sun, Y., Gao, M., Xu, M., Li, S., Li, Y., Li, C., 2018. Interaction Effects of pH and Lipopolysaccharide or Histamine on mRNA Expression Levels of Tight Junction Proteins of Rumen Epithelium of Dairy Goats in Vitro. Journal of Animal Nutrition. 30, 1816-1826.

Uto, T., Morinaga, O., Tanaka, H., Shoyama, Y., 2012. Analysis of the synergistic effect of glycyrrhizin and other constituents in licorice extract on lipopolysaccharideinduced nitric oxide production using knock-out extract. Biochem Biophys Res Commun. 417, 473-478.

Vaya, J., Belinky, P., Aviram, M., 1997. Antioxidant constituents from licorice roots: isolation, structure elucidation and antioxidative capacity toward LDL oxidation. Free Radic Biol Med. $23,302-313$.

Wang, H., Zhao, H., Sui, Y., et al., 2015. Effect of Lipopolysaccharide on the Expression of TLR2 and TLR4 in Intestinal Mucosa Microvascular Endothelial Cells. China Agricultural Bulletin. $31,72-77$

Wang, L., Dong, Z., Huang, B., et al., 2010. Distinct patterns of autophagy evoked by two benzoxazine derivatives in vascular endothelial cells. Autophagy. 6, 1115-1124. 
bioRxiv preprint doi: https://doi org/10.1101/2020.05.27.118570; this version posted May 28, 2020. The copyright holder for this preprint

(which was not certified by peer review) is the author/funder, who has granted bioRxiv a license to display the preprint in perpetuity. It is made available under aCC-BY 4.0 International license.

404

405

406

407

408

409

410

411

412

Wang, T., 2015. Effect of rumen histamine on inflammatory pathway of rumen epithelial cells in cattle with subacute rumen acidosis. Jilin University.

Wang, X., Hao, H., Chu, L., 2017. Glycyrrhizin inhibits LPS-induced inflammatory mediator production in endometrial epithelial cells. Microbial Pathogenesis. 109, 110-113.

Wellnitz, O., Amold, E.T., Bruckmaier, R.M., 2011. Lipopolysaccharide and lipoteichoic acid induce different immune responses in the bovine mammary gland. Dairy Sci. 94, 5405-12.

Wellnitz, O., Kerr, D.E., 2004. Cryopreserved bovine mammary cells to model epithelial response to infection[J].Vet Immunol Immunopathol. 101, 191-202.

Wullaert, A., Bonnet, M.C., Pasparakis, M., 2011. NF-kB in the regulation of epithelial homeostasis and inflammation. Cell Res. 21, 146-158.

Wu Y., 2013. Effects of subacute rumen acidosis on proliferation and apoptosis of rumen and valvular epithelial cells. Agricultural University Of The Inner Mongol.

Xu, L., Sun, D., Zhang, Y., Zhang, Z., Li, X., 2010. Relationship between occludin expression in intestinal epithelial cells and tumor necrosis factor-alevel in rats with nonalcoholic fatty liver disease. Chinese Digestive Journal of the World. 18, 981-986.

Xu, Y., Kim, S.O., Li, Y., et al., 2006. Autophagy Contributes to Caspase-independent Macrophage Cell Death.The Journal of Biological Chemistry. 281, 19179-19187.

Yamamoto Y, Kitamura N, Yamada J, Yamashita T (1993) Three-Dimensional Architecture of the Subepithelial Connective Tissue in the Omasal Laminae of Sheep and Cattle. Cells Tissues Organs 146, 238-243. 
424 Yamashita, T., Asano, Y., Taniguchi, T., Nakamura, K., Saigusa, R., Miura, S., et al., 2017.

425 Glycyrrhizin ameliorates fibrosis, vasculopathy, and inflammation in animal models of

426 systemic sclerosis. Investig. Dermatol. 137, 631-640.

427 Yan, Z., 2014. Effect, Mechanism and function Analysis of LPS treatment on FTO expression in

$428 \quad$ Broiler chickens. Agricultural University Of Nanjing.

429 Zhang, R., Zhu, W., Mao, S., 2016. High-concentrate feeding upregulates the expression of 430 inflammation-related genes in the ruminal epithelium of dairy cattle. J Anim Sci Biotechnol. $29,7: 42$

Zhang, Y., Yang, J.W., Ren, X., Yang, J.M., 2011. NAC1 and HMGB1 enter a partnership for manipulating autophagy. Autophagy.7(12), 1557-1558.

434 Zhao, C., 2019. The mechanism of inflammation of rumen and the changes of rumen epithelial

435 SLC22A transporter proteins in dairy cows with SARA. Jilin University, Ph.D. thesis, China.

436 Zhu, J., Tan, X.R., 2011. Research advances in ROS and autophagy. Life sciences. 10, 987-992. 
Figure 


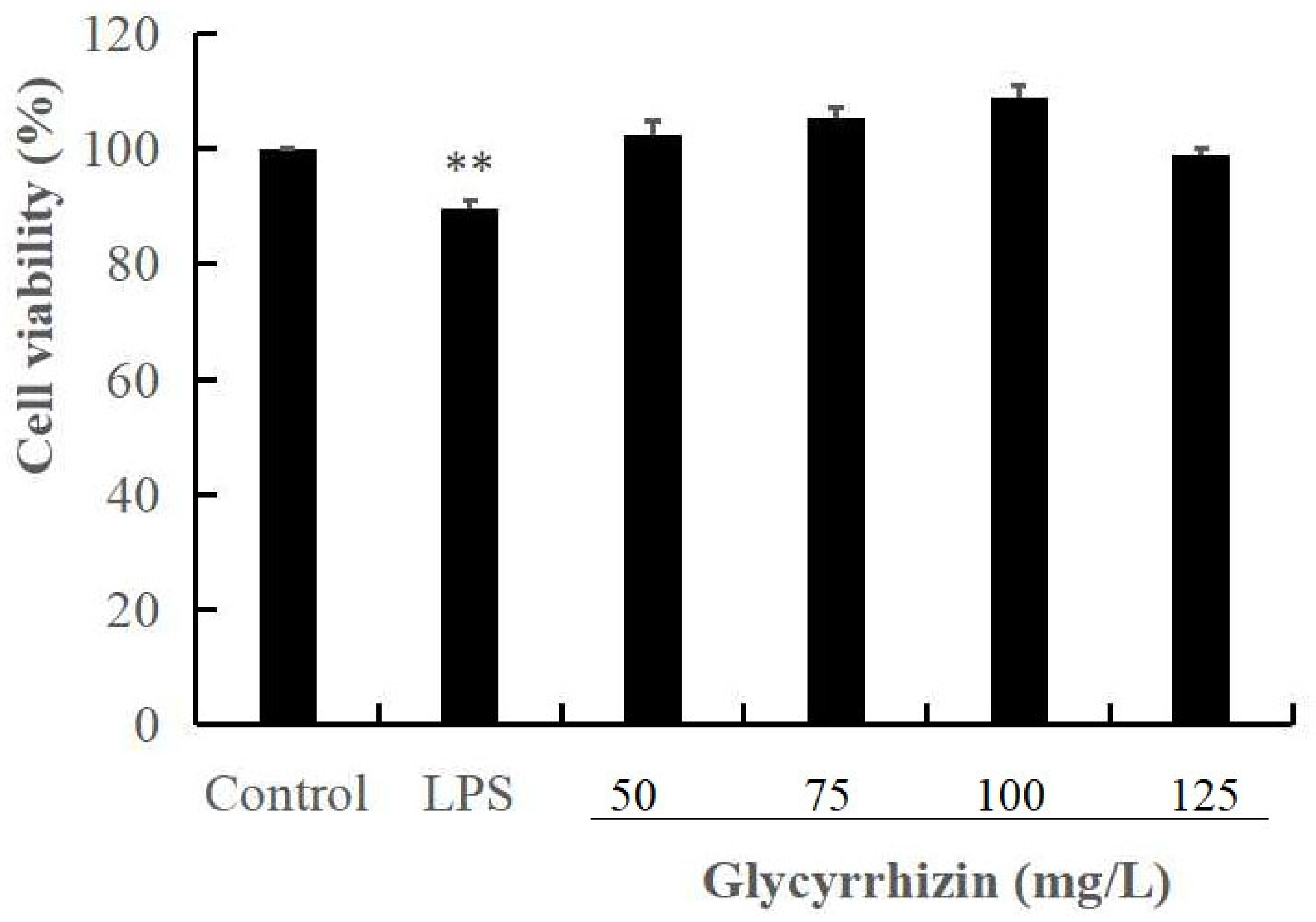

Figure 

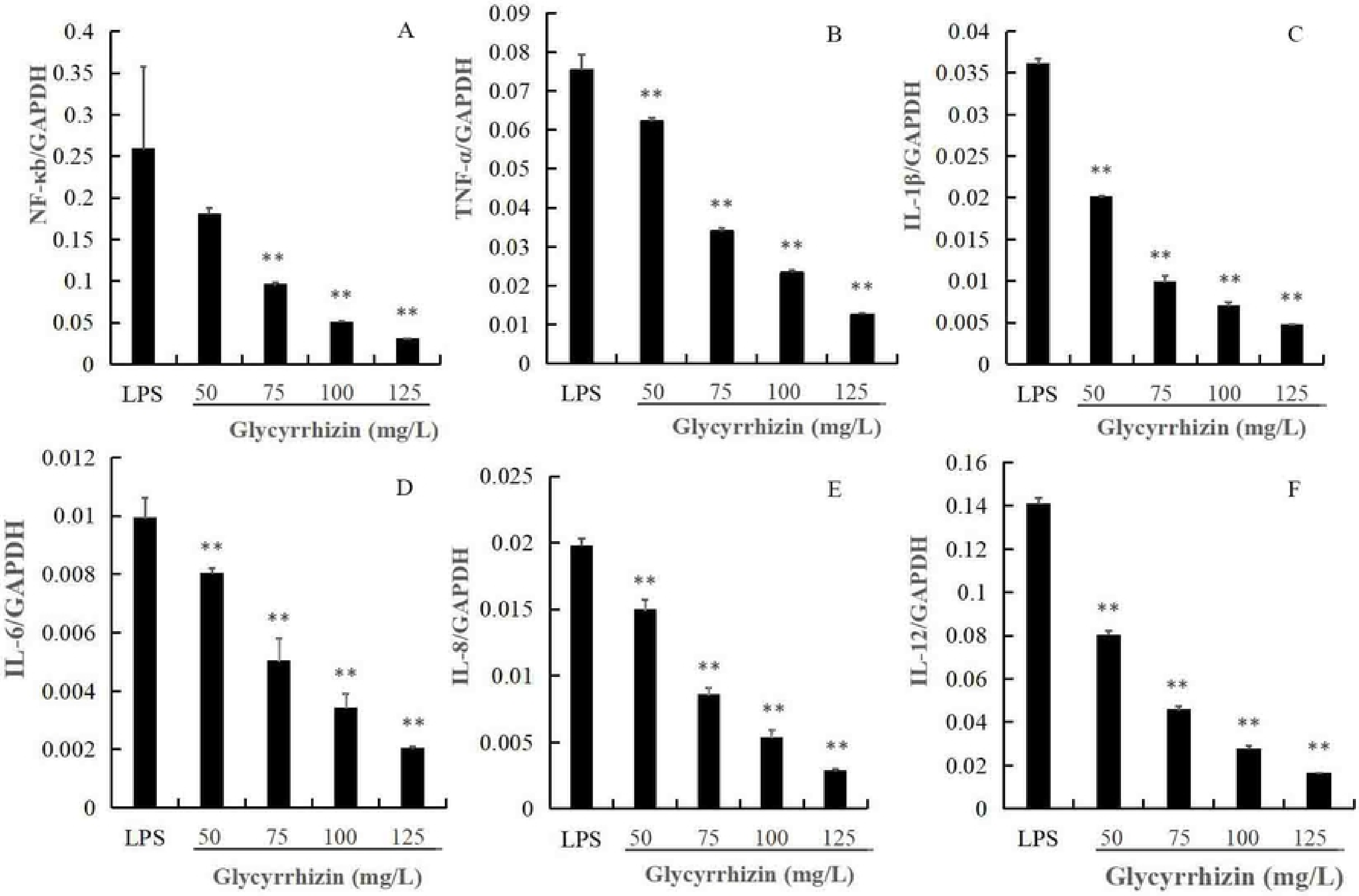

Figure 


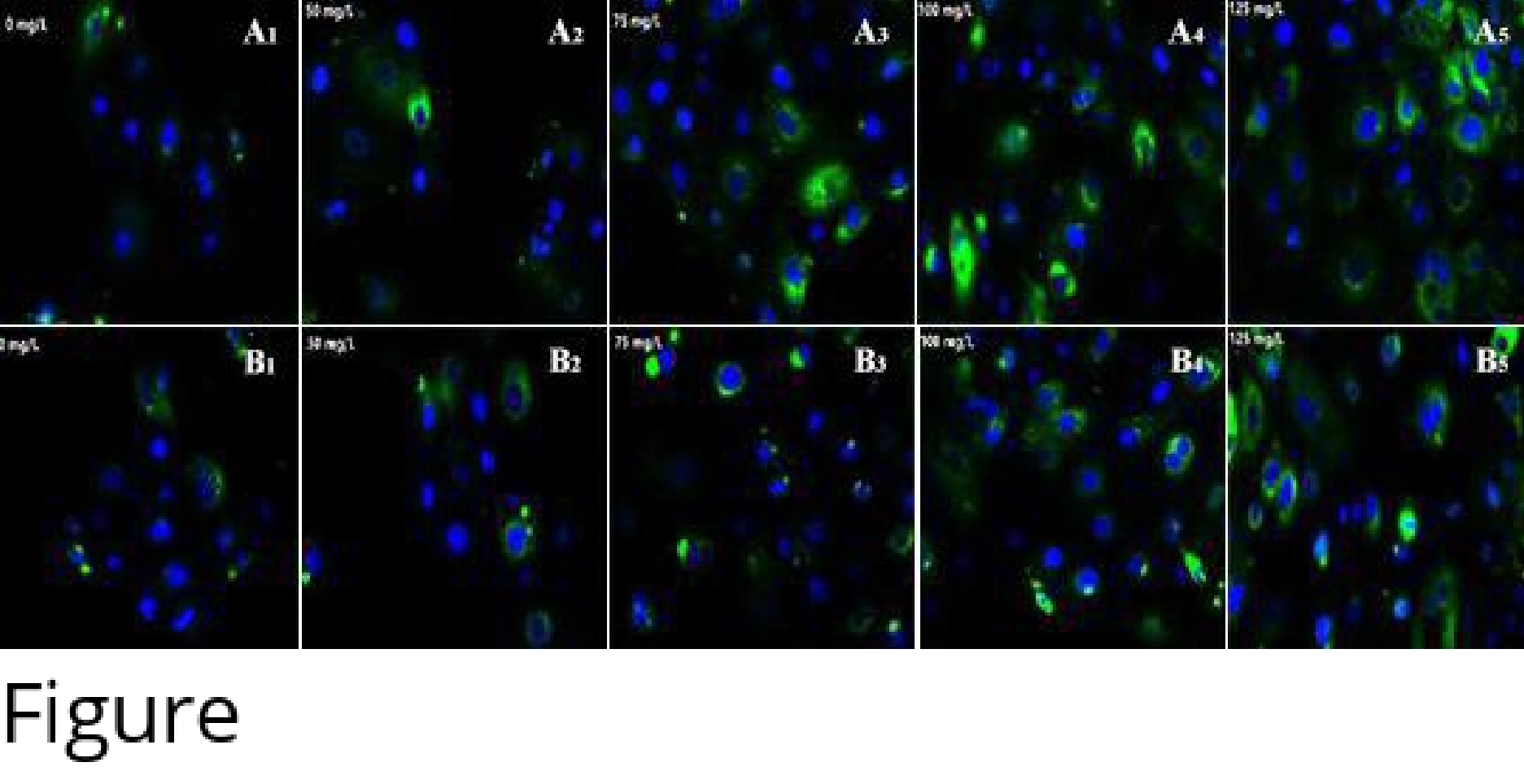


A

LPS $\quad 50 \mathrm{mg} / \mathrm{L} \quad 75 \mathrm{mg} / \mathrm{L} \quad 100 \mathrm{mg} / \mathrm{L} \quad 125 \mathrm{mg} / \mathrm{L}$

0ccludin

$\beta$-actin

B

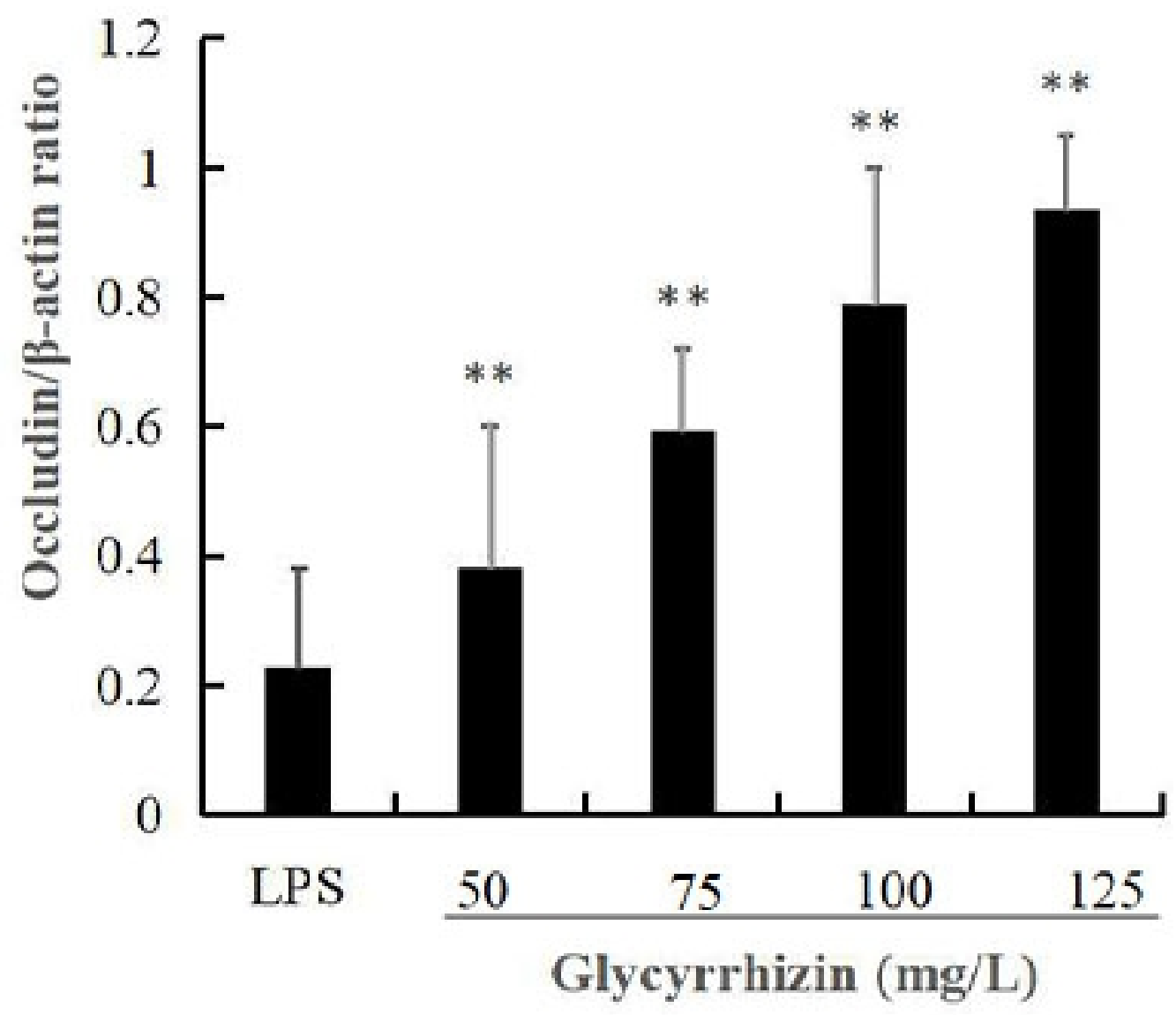


1 Fig. 1. Immunocytochemistry of purified epithelial cells. Purified epithelial cells were obtained by

2 digestion, and identified by the detection of cytoskeleton 18 .

3 Fig. 2. Effects of LPS and glycyrrhizin on cell viability of GRECs. The cell viability was

4 measured by MTT assay. GRECs were incubated with LPS at the concentration of $50 \mathrm{mg} / \mathrm{L}$, and

5 glycyrrhizin at the concentration of $0,50,75,100$ and $125 \mathrm{mg} / \mathrm{L}$, respectively. The data presented

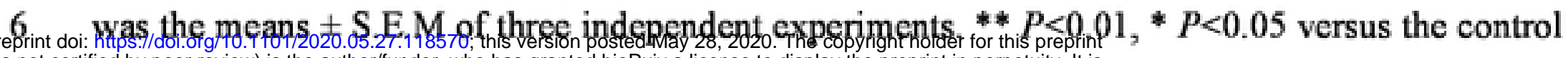
(which was not certified by peer review) is the author/funder, who has granted bioRxiv a license to display the preprint in perpetuity. It is
made available under aCC-BY 4.0 International license.

7 group.

8 Fig. 3 (A-E). Effects of glycyrrhizin on LPS-induced inflammatory cytokines. GRECs were

9 incubated with $50 \mathrm{mg} / \mathrm{L}$ of LPS for $2 \mathrm{~h}$, and then glycyrrhizin $(0,50,75,100,125 \mathrm{mg} / \mathrm{L})$ was

10 added for $24 \mathrm{~h}$. Inflammatory cytokines of TNF- $\alpha$ (A), IL-1 $\beta$ (B), IL-6 (C), IL-8 (D) and IL-12 (E)

11 were measured by Elisa kits. The data presented were the means \pm S.E.M of three independent

12 experiments. ${ }^{* *} P<0.01,{ }^{*} P<0.05$ versus LPS group.

13 Fig. 4 (A-F). Effects of glycyrrhizin on the relative mRNA expression of NF-kB, TNF- $\alpha$, IL-1 $\beta$,

14 IL-6, IL-8 and IL-12 in LPS-induced GRECs. GRECs were stimulated with $50 \mathrm{mg} / \mathrm{L}$ of LPS for 2

$15 \mathrm{~h}$, and then were incubated with glycyrrhizin $(0,50,75,100,125 \mathrm{mg} / \mathrm{L})$ for $24 \mathrm{~h}$. The relative

16 mRNA expression of NF-kb (A), TNF- $\alpha$ (B), IL-1 $\beta$ (C), IL-6 (D), IL-8 (E) and IL-12 (F) was

17 measured by qRT-PCR. The data presented were as the means \pm S.E.M of three independent

18 experiments. ${ }^{* *} P<0.01,{ }^{*} P<0.05$ versus LPS group.

19 Fig. 5 (A-B). Effects of glycyrrhizin on the distribution of Zo-1 and Occludin in LPS-induced

20 GRECs. GRECs were stimulated with $50 \mathrm{mg} / \mathrm{L}$ of LPS for $2 \mathrm{~h}$, and then were incubated with

21 glycyrrhizin $(0,50,75,100,125 \mathrm{mg} / \mathrm{L})$ for $24 \mathrm{~h}$. The distribution of the Zo-l $\left(\mathrm{A}_{1}-\mathrm{A}_{5}\right)$ and 
22 Occludin $\left(B_{1}-B_{5}\right)$ was measured by immunofluorescence staining. Fig. $5\left(A_{1}-A_{5}\right)$ and Fig. 5

$23\left(\mathrm{~B}_{1}-\mathrm{B}_{5}\right)$ represented the LPS group and LPS-induced GRECs treated with glycyrrhizin at the dose 24 of $50,75,100,125 \mathrm{mg} / \mathrm{L}$, respectively.

25 Fig. 6 (A-B). Effects of glycyrrhizin on the expression of Occludin in LPS-induced GRECs.

26 GRECs were incubated with $50 \mathrm{mg} / \mathrm{L}$ of LPS for $2 \mathrm{~h}$, and then were incubated with glycyrrhizin at

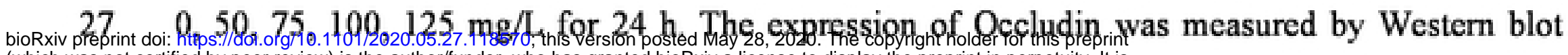

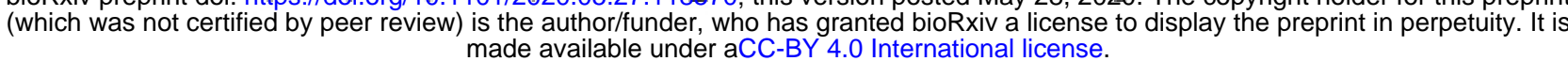

28 analysis. $\beta$-actin was used as a control, the values presented were the means \pm S.E.M of three independent experiments. ${ }^{* *} P<0.01,{ }^{*} P<0.05$ versus LPS group.

Fig. 7 (A-E). Effects of glycyrrhizin on morphology of LPS-induced GRECs. GRECs were

31 incubated with LPS for $2 \mathrm{~h}$, and glycyrrhizin was added at the dose of $0,50,75,100,125 \mathrm{mg} / \mathrm{L}$

32 from picture A to E. The autophagy around the nucleus was the highest in fig. A, and it gradually decreased in fig. C, fig. D and fig. E. 